\title{
Hyrdeliv og paradisdrøm. Om Grundtvigs syn på hyrder
}

\author{
Af Inger Lise Mikkelsen
}

Grundtvig levede $\mathrm{i}$ en tid, hvor enhver digter skrev naturlyrik eller hyrdepoesi. Den er en arv fra det 18. århundredes opg ør med oplysningstidens forstandskultur. Bevægelsen frem mod en ny naturfølelse med religiøs dragning begyndte i England, hvorfra den bredte sig ud over hele Europa. Her blev hyrden, der blidt leder sin hjord gennem grønne enge, tidligt symbol på den natur, mennesket skal vende tilbage til. Sammen med barnet repræsenterer han det oprindeligt uspolerede menneskeliv. Som barn af sin tid, tog Grundtvig hyrden til sig, og tildelte ham en central plads i sit rige billedunivers.

I tilknytning til Christian Thodbergs forskningsindsats analyserer jeg hyrdetemaets betydning for Grundtvigs menneskesyn i sammenhæng med hans forståelse af gudstjenesten. Undersøgelsen foretages på grundlag af Grundtvigs Sangværk (GSV) og hans prædikener fra 1820erne (GP), suppleret med enkelte uddrag af »Verdens Krønike« 1814 (VK 1814) og »Poetiske Skrifter« (P.Skr.) v. Sv. Grundtvig, bd. 4.

\section{En hyrdeslagt}

Når Grundtvig hævder, at det hebraiske sprog står det paradisiske grundsprog nærmest, og dermed gør jøderne til det mest poetiske folkefærd i historien, er det værd at bemærke hans vurdering af dette folk som en slægt af Hyrder.

Grundtvig antager, at Noa og navnlig Sem har beholdt meget af grundsproget. Af Noas børn er Sem det åndeliges fader. Det vil for Grundtvig sige, at han blev stamfader til alle dem, »der havde brugt et Tungemaal Ebræernes ligt.«(VK 1814 s. 58)

Svarende til Sems særlige poetiske sans, skal man ikke forvente at finde ham og hans slægt $\mathrm{i}$ faste huse, men på stadig vandring under åben himmel. Sems efterkommere blev hyrder. De er fortrolige med alt, hvad der lever og gror på sletterne, hvor de går med deres kvæg. Frigjort, som de er fra alt materielt, kan de ubekymret lade ånden føre sig, og derigennem genkende noget af sig selv i naturen. Som 
blomsterne folder sig ud på marken, således vækkes hyrdens forestillingsevne, og hans syner fødes. Hvad blomsterne og det græssende kvæg er for øjet, er synerne for hjertet. Begge dele er levende billeder på Guds skaberkraft og hyrdens afhængighed af sin skaber.

Når hyrdens syner fødes, skyldes det, som antydet, ikke hans egen skabende evne. Hans fantasi er netop ikke skabende - »den er ydmygt genkendende. ${ }^{1}$ Han må vente på Guds indgriben, som sætter ham $\mathrm{i}$ stand til at danne billeder og omsætte dem i et poetisk billedsprog, så han synger, hvad han skuer.

Forudsætningen for at kunne lade sig gribe af Guds kraft ligger i et sandt hyrdeliv, som minder om paradislivet. Efter Grundtvigs mening er hyrden derfor det stof, Gud skaber skjalde af. Det bør således ikke undre os, at vi »finde de gamle Patriarcher og hartad al Sems Afkom ved Hyrdestaven:« (VK 1814 s. 68f).

\section{Hyrder i Det gamle Testamente.}

\section{Abraham}

Abraham »fik Pant paa Himmel-Sæden, « (GSV II 94,1). Derfor kan ingen måle sig med ham »I Lykke, i Hæder og Ære, « (GSV II 56,11). Det er ikke sådan, at Abrahams lykke skyldes hans egen fortjeneste. Den lykke og velsignelse, der bliver ham til del, skyldes alene, at Gud valgte ham som stamfader til sit folk (GSV II 10,1). I gengivelsen af Abrahams kaldelse anslås den fortrolige tone, der kendetegner hans særlige forhold til Gud.

Farvel, sagde Abraham Fædreneland!

Farvel mine Venner og Frænder!

Jeg følger min Gud, for min Glæde er Han,

Min Hjelper til Jorderigs Ender. (GSV II 10,6)

Hvor man ellers kunne forvente, at Abraham følger Guds ord af lydighed, anfører Grundtvig en anden årsag. Abraham bryder op fra sit fædreland, fordi Gud er hans glæde. Det, der føder glæden, er tilliden til Guds ord, at gennem Abraham skal hele jorden velsignes. Det er just denne tillid, som traditionelt kaldes »tro « eller »troens tillid«, der giver Abraham status som »Herrens Ven« (GSV II 11,5). 
Blandt de lejligheder, hvor Gud lover, at den velsignelse, der skal udgå til alle jordens folk fra Abraham, i næste slægtled skal gå gennem Isak, vælger Grundtvig at gendigte Gen 18,1-15 om Guds besøg hos den ældgamle »Hyrdedrot«, Abraham ved Mamres Lund, hvor Gud smagte »Jordens Brød.« (GSV II 11,6-7).

Herren da siger til sin Ven,

Alt som Han bryder Brødet:

»Naar om et Aar vi sees igien,

har Sara Søn paa Skiødet!« (GSV II 11,8)

Måltidsfællesskabet er et billede på paradisets herlighed ved tidernes ende, den som kristne får en forsmag på ved gudstjenestens nadverfællesskab. Abrahams måltid sammen med Herren selv er dog kun et dunkelt forvarsel om, hvad kommende slægter skal opleve.

Abraham får et synligt tegn (brødets brydelse) og hører et lydeligt ord (forjættelsen), og han »tog det Ord med Tro, " (GSV II 11,9). ${ }^{2}$ Fordi han modtog Ordet og tilegnede sig det i tro, blev han fader til Gudsfolket og et forbillede til efterfølgelse i troen for alle kristne.

\section{Isak og Jakob}

Grundtvig giver aldrig patriarken Isak hyrdestatus. Det hænger sammen med at denne markerer sig uheldigt, idet han alle dage foretrak skytten Esau frem for hyrden Jakob, selv om Gud havde sagt: »Den Større er dog den Mindre (GSV II 14,2 jvf. Gen 25,23). Isak hænger ved det materielle og kan derfor ikke være forbillede for et ret forhold mellem Gud og menneske. Her findes måske forklaringen på, at Grundtvig ikke gendigter forjættelsen til Isak (Gen 26,111). Men da Isak er et uundværligt led i patriarktriaden, må Grundtvig medgive, at han arvede »Velsignelsen hernede." (GSV II 56,13).

Isaks søn Jakob er derimod en af Grundtvigs nøglepersoner. Det kan ikke undre, for det var hans stjerne, der sprang ud julenat og blev til en sol (GSV III 67,22). Af alle fortællinger om Jakob stod Gen 28,10-22, om drømmen i Bethel, Grundtvig særlig nær (GSV II 15). I gendigtningens indledende strofer fortælles, hvordan den flygtende Jakob under savnet af sine forældre og angst for Esau alligevel kan lægge sig trygt til ro under åben himmel. Det kan han, 
fordi »Han var af den gamle Tro« (GSV II 15,5) og derfor falder i søvn under bøn, og:

\author{
Maanen skinned høit i Sky, \\ Alle Stjerner blinked, \\ Jakob sov i Himlens Ly, \\ Engle da ham vinked, \\ Sødt det for hans Øre sang, \\ Drømmesyn fra Gladhjems Vang \\ For hans Øie svæved.(GSV II 15,6)
}

Naturen er hjemlig fortrolig. Nattehimlen er i bevægelse på en måde, der minder om situationen i »Dejlig er den Himmel blaa.« Stjernerne blinker og englene vinker. Det er ikke tilfældigt, for stjerner og engle er altid billeder på godt nyt fra Gud. I det lys, der omskinner Jakob fra himmelstigen, får han lov til at se ind i Guds fremtid. Oppe fra toppen af englestigen gentager Gud Abrahams velsignelse for Jakob, og lover at beskytte ham alle dage (strofe 7-11). Med den betydning Grundtvig tillægger forbindelsen mellem billede og lyd, er det ikke mærkeligt, at synet forsvinder, da Gudsrøsten tier. Jakob forfærdes. Han vidste ikke »At Vor Herre var saa nær« (Strofe 12). Det bliver han først for alvor mindet om, da det gryer ad dag:

Soel oprandt og Lærken slog
Mildt i Morgenrøden,
Vandringsstaven Jakob tog,
Sørged ei for Føden,
Haabefuld i Herrens Navn
Faders Huus og Moders Favn
Ryggen nu han vendte. (GSV II 15,15)

I det danske sommerlandskab ser Jakob meningen med sit drømmesyn og dermed meningen med sit liv. I VK 1814 (s. 68) hedder det, at $i$ alt hvad der omringer hyrden $» s k u e r$ han Spor af det Usynlige og en Lignelse af sit Levnet og sin Idræt." Her er lærken, der stiger syngende op mod solopgangen, et billede på Jakobs paradisiske oprindelse. Som klareste billede på menneskets evne til at tale og synge, det, der adskiller mennesker fra dyr, er den syngende lærke også billede på menneskets bestemmelse, som er altid at skulle takke 
og lovprise Gud. ${ }^{3}$ Jakobs situation er det fortabte menneskes situation. Den er ganske som fuglens. Udsat og prisgivet som den, lægger Jakob sit liv i Guds hånd.

Guds løfter i nattens drømmesyn og synet af sommerlandskabet har vakt paradismindet til live. Jakobs udfærd er i virkeligheden en hjemfærd, nemlig hjemfærden til en uendelig tryghed under Guds omsorg.

Moses

»Ja, siden der Israel blev plaget i Ægypten og Herren havde opvakt sit Folk en Befrier i Moses kom denne vel til Hove og blev oplært i al Ægypternes Viisdom; men han maatte tilbage til Ørken og dannes under Hyrdelivet til sit store Kald-« (GP 1 s. 167)

Moses' store kald er som bekendt, at han skal føre Israel ud af Ægypten til det land, Gud lovede fædrene. Ved hoffet er Moses blevet oplært i en livsanskuelse, der alene bygger på det materielle. Derfor skal han gøres skikket til at påtage sig sin opgave. Han skal, for at kunne lede folket tilbage, selv ledes tilbage til Abrahams, Isaks og Jakobs Gud. Under hyrdelivet i ørkenen forsvinder »Hver PrindseNykke fra Kongesal« (GSV II 23,4). Herude lærer Moses omsider, at han ikke lever af sin egen, men af Guds visdom. Til at skildre Moses' sindsstemning, griber Grundtvig til Ps. 90, hvor Moses erkender afstanden mellem Gud og menneske i mistrøstige toner.

Som Blomsten falmer hver Rosenkind,

Som Græs er de Kæmper gæve,

De Vises konstige Hjernespind

Henveires som Spindelvæve. (GSV II 23,8)

Overfor Gud, for hvem vort tidsbegreb ingen gyldighed har, kan den beregnende kolde menneskeforstand intet stille op. De lærdes spidsfindigheder skal forgå, for målt med guddommelig målestok er et menneskeliv så kort som en plantes. Det korte menneskeliv er fyldt med strid og besvær, og skulle »en Kæmpe« opnå sin firsårsdag, »Desmere han har at døie.« (GSV II 23,9).

Til Moses' skuffede livserfaring lægger Grundtvig sin egen kommentar. 
Om Hjertet blev det ham nu saa trangt,

Paa Kinden ham Taaren trilled,

Engang var Livet ham rigt og langt,

Mens Lykken kun for ham spilled. (GSV II 23,10)

Når det bliver Moses trangt om hjertet, så han med tårer mindes livet, som det var engang, er det givetvis ikke livet ved Faraos hof, der tænkes på, men erindringen om livet i paradis under Guds varetægt. Det er mindet om »Det dejlige land«, der giver Moses kraft og mod til at bede.

Han bad: O Herre i høien Hald!

Du lære mig ret af Naade

At regne paa mine Dages Tal

Og lade din Viisdom raade! (GSV II 23,11)

Det er interessant, at Grundtvig i denne strofe ændrer bibeltekstens kollektive vi-form (Ps 90,12) til jeg-form, således at bønnen på dette sted bliver strengt personlig. Dermed understreger han, at det først og fremmest er Moses eget eksistentielle problem, det handler om. Først da Moses erkender, at han kun lever af Guds nåde, bliver han kaldet til sin opgave, men Moses vægrer sig ved at gå Guds ærinde med den begrundelse, at han mangler talegaver, ja værre endnu, han kan kun »læspe og stamme « (GSV II 23,27). Moses' talefejl er ikke hans alene. Efter Grundtvigs opfattelse er det faldne menneskes situation netop bestemt af en manglende evne til at bruge sproget som udtryksmiddel. ${ }^{4}$ Men Gud, som er hævet over menneskelig ufuldkommenhed, gør altid det uventede. Hans visdom kommer altid til udtryk i de små og svage. Derfor ophøjer Gud det, som intet er i egne øjne. Det er forklaringen på, at Moses, sin lange udlændighed til trods, kan tale med Gud »Som en Mand under Sol med sin Næste, « (GSV II 34,4 jvf. 2.Mos 33,11). På ørkenvandringen lægger Grundtvig særlig vægt på Moses isolerede position i forhold til folket, og i den forbindelse hans aldrig svigtende håb, hvis handlende udtryk er bønnen. Moses er den store ensomme kæmpe i Israels historie. I det frelseshistoriske perspektiv genfindes hans situation hos Luther.

»....nu opvakde Gud i ham (Luther) en Moses for sit christne Folk, som udførde dem af et ægyptisk Trældoms-Aag, lærde dem igien 
at kiende Abrahams og Isaks og Jakobs Gud, vor Herres Jesu Christi Fader som Han vil kiendes og tilbedes i Aand og Sandhed.« (GP 1 s. 427)

\section{David}

Ingen hyrde udfylder sin bestemmelse som Guds skabning så fuldkomment som David, "Manden med den lifligste Psalmetunge i Israel.« Derfor passer fuglen som billede på menneskets guddommelige oprindelse ganske særligt på ham.

Jeg gik i Marken og vogtede Faar,

Slog min Harpe i Skyggen af Palmer,

Glad som en Fugl i den faureste Vaar

Hopped rundt jeg og nynned paa Psalmer! (GSV II 47,1)

Siden oplever David sit inderlige forhold til Gud under kongesalvingen, hvor olien han salves med falder »Som en Dugg over Græsset $\mathrm{i}$ Dalen!« (GSV II 47,4) jvf. Ps.72,6 om kongen »Han kommer som regn på slagne enge...«

Mange i Salen saa skævt til mit Held, Ikke vidste dog nogen min Lykke, Lønlig udsprang der i Barmen et Væld, Som en Kilde i Palmernes Skygge (GSV II 47,5)

Der er ingen særlig glans forbundet med salvingen, ingen engle viser sig og ingen Guds-røst lyder. Det er i overensstemmelse med det bibelske forlæg (1.Sam 16). Det eneste synlige billede på Guds velsignelse over David er olien. Den fremkalder et skjult kildevæld i Davids indre. Det er det skjulte væld i barmen, dvs. hjertet, der giver David kongeværdigheden. Den er for Grundtvig det samme som hyrdedrengens gudbilledlighed.

»Og da Herren vilde give dem en Konge efter sit Hjerte, og udvalgde David, sin Tjener, da tog Han ham, som skrevet staaer, (Ps 78) fra Faare-Stierne, fra at gaa efter Faarene, som vare med Lam lod Han ham komme til at føde Jakob sit Folk og Israel sin 
Arv han fødte dem efter sit Hjertes Fuldkommenhed og ledte dem ved sine Hænder med megen Forstand og han sang (Ps 23) Herren er min Hyrde....« (GPP 1 s. 168)

Det centrale i anførte citat er, at Gud vælger Israel en konge efter sit eget hjerte. Det betyder, at Gud udvælger en konge, hvis hjerte han har dannet så fuldkomment som et menneskehjerte kan være i forhold til Guds eget hjerte. David har et hjerte, der er en jordisk genspejling af Guds hjerte, som er kærlighed.

Derfor er der hos David overensstemmelse mellem følelse og forstand, mellem åndeligt og legemligt, så at han føler kærlighed til Gud med hjertet og forstår Guds vilje med hjernen. ${ }^{5}$ Derfor var David skaberen »Hjertelig kiær« (GSV II 56,30), men det er vigtigt at være opmærksom på, at et fuldkomment hjerte ikke er ensbetydende med frihed for synd.

Grov var hans Synd, men hans Sorg var og sand, Saa dyb, som det bundløse Hjerte, Naaden ham favned og reiste paa Stand, Til Trøst den forvandled hans Smerte. (GSV II 56,32)

Guds barmhjertighed er uden ende, men kun den, der angrer, kan føle nåden tilsagt. Nåden er personificeret. ${ }^{6}$ David favnes af den, så hans smerte forvandles til trøst. Da David er underlagt synden og handler på dens vilkår, tydes hans hjertes fuldkommenhed antagelig bedst som hjertets oprigtighed, fordi den af hjertet oprigtige erkender sig selv som skabning overfor sin skaber.

Gennem historiens løb er hyrdernes grundvilkår det samme, idet de alle forstår sig selv som skabt i Guds billede, men deres ydre vilkår er forskellige til forskellig tid. Derfor giver Gud dem bestemte evner, der svarer til deres konkrete historiske situation. Patriarkerne (her Abraham og Jakob) levede, medens ejendomsretten til det forjættede land endnu ikke var markeret med fast bosættelse. Hos dem betones særligt troen. Moses, der førte folket tilbage til landets grænse, har navnlig sans for Guds visdom i modsætning til menneskers visdom og frem for alt kampen, hvilket vil sige bønnen, som middel til at bevare håbet. David blev konge i landet. Han er ganske særligt kærlighedens hyrde, hvis hjerte-lighed med Gud er det klareste billede på Guds bestemmelse med mennesket. 
Set $\mathrm{i}$ et videre perspektiv, så er Grundtvigs fremstilling af Guds historie med Israels hyrder, foruden en historie om individuelle skæbner, også en karakteristik af menneskelivets vækst fra frelsens begyndelse med forjættelse og tro, gennem kampår i håb, indtil frelsens fuldendelse i Guds rige, hvor kun kærlighed råder.

\section{Ufuldendte digte om julens hyrder}

Grundtvigs optagethed af hyrder måtte føre til en gennemtænkning af hyrdernes betydning for juleevangeliet. Det første forsøg på at skildre hyrdernes oplevelse julenat dateres i sangværket til 1810 (GSV III 10) og nævnes som et muligt forarbejde til »Dejlig er den himmel blå«.(GSV VI s. 186)

Hyrderne ser sære himmeltegn. En stjerne, der glimter frem bag drivende forskelligfarvede skyer, forstår de ikke at tyde. Det gør heller ikke en gammel gubbe, der har levet så længe, at »Hjertet under hvide Haar/Saa barneligt er blevet.» (GSV III 10,4). Digtet afbrydes, inden Grundtvig når frem til at formulere en mening med skyernes farve og bevægelse og inden det glade budskab, der bliver hyrderne forkyndt af engle.

I 1817 vender han igen tilbage til motivet (P.Skr. bd.4. s. 414429). Da var det hans mening at skrive et episkdramatisk juledigt svarende til »Paaske-Liljen» fra samme år. I det ufuldendte digt, der bærer titlen »Jule-Natten eller Hyrderne ved Betlehem,» skildres en samtale mellem den gamle hyrde, Rekab, og nogle unge. Overfor en ung, glemsom hyrde, priser Rekab hyrdelivet i høje toner og minder ham om, at med sin frihed fra næringssorger, burde hyrden have sindet åbent for Guds skaberværk, og deri kunne genkende noget af sit liv. Ifølge Rekab er det derfor ikke tilfældigt, at hyrder ikke bygger huse, »Men altid nøjes med et svagt Pavlun/Som minder os om det, hvori vi bygge/En liden Stund, og vandre til vor Grav.» (s. 415).

De unge hyrder har mødt den højgravide jomfru Maria. Det giver anledning til en diskussion om, hvorvidt englesyner og profetier er troværdige. En af de unge har været i synagogen, hvor lærde folk fra hovedstaden har gjort ham til tvivler. Overfor ham fremhæver Rekab Israels store sønner. Frem for alt David, der fandt stenen til sin slynge, hvormed han slog Goliat, ikke blandt de vældige i Judæa, 
men her på egnen ved Betlehem. Ude i Guds egen natur »stod for Herrens Ansigt Abraham»...og her,..»som en Mand kan tale med sin Næste,/Med Moses talte alle Guders Gud« (s. 425). Den unge hyrde føler sit hjerte »som forstenet, « (s. 426) og beder den gamle fortælle mere, men manuskriptet afbrydes midt i Rekabs bemærkning om, at Gud kun sender engle i ganske særlige ærinder.

\section{Det kimer nu til julefest}

Samme år som Grundtvig opgav det dramatiske juledigt, gendigtede han Luthers salme "Vom Himmel hoch da komm ich her.« (Frit fordansket ifølge Grundtvig selv, GSV III 67). ${ }^{7}$ De syngende skal i ånden komme med til Betlehem, og gå med ud på marken for at høre englens budskab sammen med hyrderne.

Hyrderne ventede Messias, fordi han var blevet dem lovet, og »fordi de følde deres Trang til Ham.«(GP 1 s. 85), og dog turde de ikke håbe, på grund af deres egen og folkets skyld, at Gud ville åbenbare sin herlighed og sin frelse for dem.

See hist i Lysets Klædebon

Blandt Hyttebørn en Himmel-Aand

Hør Paradisets Nattergal

Slaae Jubel-Slag i Graadens Dal! (GSV III 67,3)

Lysets engel kommer på besøg hos hyttebørn. Et hyttebarn er et menneske, der, ligesom hyrderne, vandrer i »Hjertens Oprigtighed «, og således erkender, at deres bolig på jorden er en skrøbelig hytte af st $\varnothing v$ svarende til hyrdens faldefærdige bolig. For dem, der vedkender sig deres vilkår som skabninger, åbenbarer Gud sin herlighed. Kun de kan høre paradisets nattergal, i skikkelse af en engel, forkynde frelsens morgengry, ${ }^{8}$ jvf. strofe 9 , hvor der står, at »Naade-Solen giør Morgengrye.«

I Bethlehem er Christus fød,

Den Frelser-Mand fra Synd og Død,

$\mathrm{Nu}$ kom den store Løvsals-Fest!

$\mathrm{Nu}$ blev Jehovah Hyttens Giæst! (GSV III 67,10) 
Efter Ørkenvandringen havde Gud »til Hyrde-Livets Ihukommelse forordnet en Høitid: Løvsalenes Fest da Folket skulle boe i Hytter.« (GPP 1 s. 168). Nu er det den kristne menighed, der skal komme hyrdelivet ihu og gå »med rørte Sind,/Som Hyrderne til Barnet ind.« (GSV III 67,15).

Af Kristusåbenbaringen for hyrderne julenat bliver det ganske klart, hvem det var patriarkerne håbede på og David sang om.

$\mathrm{Nu}$ kom Han, Patriarchers Haab,

Med Nyaars-Vers og Himmel-Daab!

Og Barnet tyder nu i Vang

Hvad David dunkelt saae og sang! (GSV III 67,23)

Det er barnet Jesus, der kommer med » Nyaars-Vers«. Dermed understreges, at det hverken er sangerne eller digteren, der skaber sangen. Det er Kristus selv, der er skaberen. Med himmeldåb hentyder Grundtvig ganske sikkert til dåben, der giver adgang til himlen. Barnet kan være Jesus, der er kommet som opfyldelse af de gamles håb og profetier, men det kan tillige forstås som det nutidige barn, der uden besvær tyder, hvad David kun dunkelt anede. Et alternativt forslag kunne være, at Grundtvig har tænkt på begge dele. Barnet Jesus er opfyldelsen, medens det kristne barn forstår meningen med hans fødsel. ${ }^{9}$ Den kan også det voksne menneske forstå, såfremt det lærer af barnet.

»I Evangeliets Virkning paa vore Børn skal vi lære at kiende vore christne Fædres Hjerte, og bede Gud forvandle vores derefter.....Hans Lys opgaaer altid for et Barne- $\varnothing_{i e}$, hans Herlighed omskinner kun Hyrderne.«(GP 1 s. 85).

Ligesom hyrden ejer barnet en naturlig ydmyghed overfor det underfulde. Gennem børnene kan de voksne lære ydmyg tro, den som forgangne slægter varmede sig ved. Det kan ske ved, at vi beder Gud omdanne vort hjerte, så det bliver som vore fædres og dermed kommer til at ligne Guds eget hjerte. Når det sker, forvandles vi til hyttebørn og ægte hyrder. Det er den voksne, der skal blive som hyrden og som barnet, der med oprigtig alvor og ydmygt sind, beder Jesus om også at være vor hyttegæst, og holde sin julefest »i os.« 
Hyrde og barn

I en række afhandlinger har Thodberg slået fast, at for Grundtvig må den voksne gå vejen tilbage til barndommens land gennem mindet om dåben. ${ }^{10}$ Samme forsker har gjort gældende, at Grundtvig når frem til denne indsigt med digtet »De levendes Land « fra $1824 .{ }^{11}$ Temaet klinger med i julesalmen fra samme år, »Velkommen igien, Guds Engle smaa «.

Da vandre Guds Engle op og ned

Paa Psalmens Tone-Stige,

Da siger Vor Herre selv »Guds Fred «

Til dem, den efterhige,

Da aabner sig Himlens Borge-Led,

Da kommer ret Guds Rige! (GSV I 197,7)

Som Jakobs drøm gentog sig, ikke som drøm, men som virkelighed for hyrderne den første julenat, således gentages den i gudstjenesten her og nu. På toppen af englestigen står Herren selv og siger »Guds Fred « til dem der higer efter den. Dem, der higer efter Guds fred er netop dem, der nu ved at genopleve Jesu fødsel, genoplever deres egen genfødsel i dåben. Dengang Herren første gang lyste sin fred over dem. ${ }^{12}$ Med opdagelsen af dåben som stedet for vejen ad hvilken den voksne igen kan betræde sin barndoms drømmeland, kommer barnebilledet til at dominere over hyrdebilledet. Det betyder ikke, at hyrden er glemt. Han er fortsat et værdifuldt symbol på det barnlige. I nogle af Grundtvigs salmer sker det, at hyrdebillede og barnebillede veksler ubesværet i kraft af deres fælles betydningsindhold.

Barnet svøbt i Krybben lagt,

Engle-Ord til Hyrder sagt,

Det er Kiende-Tegnet!

Barnet der for Barne-Tro

Har til Øine Sole to,

Nemt det er udregnet,

De giør under Kirke-Tag

Brat en dobbelt Sommer-Dag,

Himmerig tilegnet! (GSV I 103,7) 
Med udgangspunkt i englens ord til hyrderne (Luk 2,12) den første julenat gentages julebudskabet ved hjælp af barnebilledet. Jesu fødsel genopleves $\mathrm{i}$ barnetroen. Tegnet både dengang og nu er, at barnet $\mathrm{i}$ krybben til øjne har to sole og i kirken genspejles de sole i (dåbs)barnets $\varnothing j n e$. Nogle af julenattens engle er børn.

Og der kom Barne-Engle smaa,

Som Stjernelys fuldmange (GSV II 60,8)

Og de synger på hyrdesprog.

Til Dagskiær og til Morgengry

De sang paa Hyrde-Maalet (GSV II 60,9)

I en enkelt salme melder englene til hyrderne, at den gode hyrde har ladet sig føde.

De Hyrder meldte sig føde lod

Nu Hyrden god! (GSV I 154,7)

Hyrdebilledet følger med til næste strofe.

Med Sang da prise vi trindt om Land

Den Hyrde-Skaber, den Gud og Mand (GSV I 154,8)

Endelig skal nævnes et par eksempler, hvor hyrderne er drenge, ikke voksne.

Engle-Bud kom flux til Jord

Men kun til Hyrde-Drenge (GSV III 151,7)

I en gendigtning af Ps.86 er det den syngende selv, der er hyrdedreng.

Vær nu Gud mit Lys i Mørke!

Giv din Hyrdedreng din Styrke (GSV IV 3,9) 
Grundtvigs begejstring for hyrder er ikke et udslag af bymenneskets romantiske natursværmeri, ligesom han er fjern fra enhver idealisering af barndommen i sig selv. Hyrden og barnet ejer en naturlig glæde ved det skabte liv. Derfor er de det klareste vidnesbyrd om Guds mening og mål med mennesket.

\section{Den forste jul og vor jul}

I 1846 skrev Grundtvig så det juledigt, han allerede havde haft $\mathrm{i}$ tankerne 30 år forinden, »Nat i Østen er ei saa lang (GSV IV 161 jvf. DDS 86)

Grundtvig indleder med at fortælle en historie om hvordan hyrderne, som holder nattevagt over deres hjord, sidder og taler om gamle dage, og bl.a. kommer til at tale om kong David. De unge hyrder har tilfældigt mødt Maria og Josef inde $\mathrm{i}$ byen, men de er skeptiske overfor troen på forjættelsens opfyldelse (strofe 1-6). I strofe 7 træder Grundtvig ud af historien og kommenterer personligt de unges opgivende holdning. Når ord om »Engle-Syner og SeersRøst«, læses op af en bog, lægges livet uvægerligt øde som en ørken.

Nu præsenteres den gamle hyrde, Jonathan. I modsætning til de unge, ejer han barnets tillidsfulde forventning. Den gamle kan så at sige føle morgendæmring. Han er i færd med at udlægge skriftens forjættelse, da Guds engel åbenbares i en overdådig stråleglans. (strofe 8-12). Herefter forvandles digtet til en salme med gyldighed til alle tider.

strofe 13

Venner! sagde Guds Engel blidt:

Hvorfor er nu I bange?

Kilde-Væld kun er Budskab mit

Til lutter Frydesange,

Thi han, som Jorden giør sjæleglad,

Er født til Verden i Davids Stad. 
I anden linie gengives Luk.2,10 »Frygt ikke«. Guds ord kommer ikke til dom som frygtet, jvf. Jakobs frygt da han vågnede op og så, at han sov, hvor Herren var nær. Budskabet er til frelse, et kildevæld til glæde og lovsang over hele jorden. Jesu fødsel i Davids by er glædens fødsel. Det er den glæde Abraham uklart kunne fornemme, og som var Davids skjulte kildevæld i hjertet.

\section{strofe 14}

Jesus Christus den Davids Søn,

Vor Frelser fra al Fare,

Født er han, ligger svøbt i Løn

I Krybben tag det vare!

Fra Himlen Høit kommer Julebud

Nu Ære være den Guders Gud!

Nu opfyldes Jonathans håb, de sørgende trøstes og de tvivlende gøres til skamme. Nu sker det, som sætter al menneskelig spekulation ud af kraft. I andensidste linie får Luther lov at synge med. Med elegant inddragelse af Luthersalmen $» F r a$ himlen $h ø j t$ "giver digteren sin egen salme et ekstra skær af hjemlighed, noget den syngende kan genkende.

\section{strofe 15}

»Ære være den Guders Gud!

Nu daled Fred til Støvet, Glæden springer af Svøbet ud, Som Blomsten og som Løvet!«

Saa lydt og sødt under Sky det klang,

Som alle Stjernernes Morgensang!

Denne strofe begynder med den forriges slutlinie. Til den eneste sande Gud, Jesu Kristi Faders ære, »daled Fred til Støvet,« ikke ganske enkelt til jorden, som Grundtvig først skrev, men til mennesket, som er taget af støvet og derfor skrøbeligt. I tredie linie har Grundtvig en interessant rettelse i manuskriptet. Han skrev først »Glæden springer af Hjertet ud,« (GSV VI s. 317), så det svøb glæden springer ud af, er uden al tvivl menneskehjertet, hvorfra glæden folder sig ud som blomsten og løvet om foråret. 
Bemærk, at der står springer, ikke sprang. Det er de syngende, der glæder sig over Jesu fødsel dengang og nu. Men englesangen er foreløbig datid. I englemund klang budskabet så herligt som aldrig hørt siden verdens skabelse (Job 38,7). Det er ikke underligt, for nu gælder det menneskets genskabelse.

strofe 16

Himmel-Klarhed og Engle-Sang

Dem gav os Gud med Freden,

Efter-Skin de og Efter-Klang

Har trindt i Christenheden,

Hvor Aand har Mæle og Sang har Væld,

Hvor Øine tindre hvert Julekvæld!

Her fortæller Grundtvig, hvad julefred betyder nutidigt. Himmelklarhed er udtryk for, at tågen mellem Gud og menneske er lettet, så at himlens port står åben, og englesangen er englenes »Ære være Gud i det højeste og på jorden fred..« (Luk.2,14) den første julenat. Dermed er stigen rejst igen. Det sker, dér hvor Guds Ånd giver forkyndelsen mæle, så den fremkalder lovsang, der er en efterklang af englenes lovprisning og »Stjernernes Morgensang." Sammen med lovsangen hører de tindrende $\varnothing$ jne, som er et efterskin fra dengang, der først »tændtes Lys i Skyggers Land« (GSV III 67, 22).

strofe 17

Kirke! du er vort Bethlehem,

Og alle Smaa derinde,

Eftersom det er sagt til dem,

Skal deres Frelser finde,

Med Juledags-Evangelium,

I Hjerte-Kammerets Krybberum!

Betlehem er rykket ind $\mathrm{i}$ kirken og hyrderne så at sige sammen med byen. Alle de små hyrder i kirken kan finde Jesus. Her fødes han og her står hans krybbe - i hjertekammeret!

Hyrdens bolig er Guds bolig 
Af salmen i forrige afsnit fremgik det, at de små skal finde frelseren i »Hjerte-Kammerets Krybberum, « og i salmen fra 1817 »Det kimer nu til Julefest « synger Grundtvig om Jesus, der skal være vor hyttegæst og holde sin julefest i os. I 1817-salmen blev dette »i os « ikke nærmere bestemt, men i 1824 siger Grundtvig i sin juleprædiken, at »hvert troende Hjerte" er en hytte i lighed med den ringe bolig, hvor frelseren lod sig føde (GP 3 s. 47). Derfor er der al mulig grund til at regne med, at han i julesalmen fra samme år også taler om hjertet som hytten.

Vor Hytte er lav og saa vor Dør,

Kun Armod er derinde (GSV I 197,3)

Hjertekammerets krybberum er altså intet andet end hyrdens faldefærdige hytte. Hjertet eller hytten er det sted, hvor Gud rører mennesket og taler kærligt til det, hvorved han omdanner dets hjerte til lighed med sit eget. Denne lighed med Gud kommer til udtryk i verden, når mennesket bryder ud i sang. Derfor er hytten foruden det sted, hvor gudbilledresten bor, også tilbedelsens og det vil sige kirkens sted. »Kirken er, hvor hjertet hører og synger. $\ll^{13}$ Det betyder, at de løvhytter, som Gud forordnede Israels folk at bygge til hyrdelivets ihukommelse, nu er at finde i kristnes hjerter.

Da blev det kiendt at Straale-Skytten

Som Himmel-Rum indslutter ei

Til Jorden sig har banet Vei, Et Lysthus bygt sig i Løv-Hytten

Hvorfra med Straaler op og ned

Han yttre kan sin Herlighed! (GSV V 5,4)

Hvis man holder fast ved, at hytten betyder hjertet, kan hyttebilledet i anførte citat tolkes på følgende måde. Den Gud, som himlen ikke kan rumme, har banet sig vej, dvs, har trængt sig ind i menneskehjertet, som er løvhytten, og skaffet sig hørt ved at ombygge eller omdanne løvhytten til sit lysthus, hvor kun kærlighed råder. Denne tolkning finder jeg bekræftet i følgende strofe fra den kendte salme »Dig rummer ei Himle.«

Du rører kun Støvet 
Som Vind-Pust i Løvet

Du himmelske Giæst!

Og Hytten i Barmen,

Med Kiærligheds-Varmen,

Behager dig bedst! (GSV I 57,2)

Når gudbilledligheden for Grundtvig får sit klareste udtryk i lovsangen, er det nærliggende at tolke det urolige billede af strålerne, hvormed Gud ytrer sin herlighed, som en skjult hentydning til Jakobsstigen. Den er altid på samme tid et billede på Kristi nærvær og menneskets lovprisning, der smelter sammen med englenes. Med andre ord: Efter mødet med evangeliet er hjertet eller hytten det sted, hvor stigen rejses og julenattens himmelske hærskarer synger til Guds ære. Det er ikke mange salmer, om overhovedet nogen, hvor hytten så utvetydigt er billede på hjertet som i sidst anførte citat (GSV I 57,2). Senest har Thodberg gjort rede for, at strofe $10 \mathrm{i}$ salmen $\gg T \varnothing r$ end nogen ihukomme «, handler om Kristus, der holder altergang i hjertet. ${ }^{14}$

Han som laae i Krybbe-Rummet

Bryde vil i Hytten Brød! (GSV I 13,10)

Som Jesu krybbe fra første færd stod i en hytte, således skal hans bolig vedblivende være ydmyg og hvilken bolig er mere beskeden end hyrdens? Hans bolig er en primitiv grenhytte eller han har sin bolig under åben himmel i løvtræernes skygge.

Med hyrdens hytte anbragt, hvor hjertet sidder, får mennesket således adgang til det guddommelige i sig selv, og dermed også til den herlighed det er, at vide sig under Guds omsorg.

Ud fra den her skitserede tankegang står tilbage at bemærke, at den kristne bliver mindet om hyrdelivet, hver gang han eller hun vender tilbage til sin dåb, for »her er Guds Hus, her er Himmelens Port...og jeg vidste det ikke « (Gen 28,17 og 16).

Med andre ord, dybest set er enhver kristen hyrde, som Abraham og Jakob, Moses og David. Men frem for alt ligner den døbte den gode hyrde selv, der er kommet og kommer for at forny det paradisliv, Gud skabte mennesket til. 
Noter

1 Citeret efter Henrik Wigh-Poulsen: »Digteren og Den Sandheds Ånd. Grundtvigs helligåndsteologi og den engelske romantik.« Grundtvig Studier 1991 s. 71.

2 »...når nadverordene siges, skal vi tage Herren på »Ordet « og tro, at hans kraft er til stede og er vores med brødet og vinen.» Således Thodberg: »Var Grundtvigs nadversyn luthersk? « I »Syn og sang - Poesi og teologi hos Grundtvig«, København 1989 s. 311.

3 Vedr. fuglen som billede på menneskets oprindelse og bestemmelse skal Thodbergs gennemgang af »Alt hvad som fuglevinger fik« fremhæves Grundtvig som salmedigter. I: Grundtvig og grundtvigianismen i nyt lys. Red Chr. Thodberg og A.P. Thyssen, Århus 1983 s. 167-169 og P.Balslev-Clausens analyse af fuglebilledet $\mathrm{i} » I$ falmende blade, du kølige vind «, og »Skyerne gråner og løvet falder«. »Det vingede ord «, s. 101110, Materialecentralen, København 1991.

4 Erik Krebs Jensen: »Hjertets gudbilledlighed « (i: For sammenhængens skyld udg. af Chr. Thodberg, Århus 1977 s. 72), forklarer Grundtvigs forståelse af syndefaldets virkning således: »Ved syndefaldet invalideredes sanserne, og talen blev til en hakken og stammen. Ved syndfloden formørkedes hensigten med skabelsen, og ved babelstårnet forvirredes sproget, i hvilket det sansede beskrives.«

5 E.K.J. »Hjertets gudbilledlighed « s. 79-89.

6 Det kvindelige er den forbarmende egenskab ved Gud - E.K.J. Hjertets gudbilledlighed« s. 91f.

7 Jeg tager ikke her hensyn til varianterne GSV I 160;193 og DDS 76.

8 I en anden salme kalder Grundtvig julenattens syngende engle for »Himlens Nattergale «(GSV I 81,23). Ifølge H. Toldberg er nattergalen den fugl, der synger klarest før morgengry, og som hos Grundtvig stedse er den underfulde bebudende lille grå fugl, der (sammen med nornegæst) forkynder for dem, der endnu er i dvaletilstand. Her citeret efter Thodberg $\mathrm{i}$ artiklen »Vejen tilbage - et Jerusalemmotiv hos Grundtvig.« Dansk Teologisk Tidsskrift (DTT) 521989 s. 303. 
9 Jeg tilslutter mig Thodberg, som tolker strofe $12 \mathrm{i} »$ Dejlig er den himmel blå« ud fra samme dobbelt perspektiv.»Vejen tilbage« DTT årg. $1989 \mathrm{nr}$. 52, s. 289.

10 Grundlæggende må henvises til bogen »En glemt dimension i Grundtvigs salmer - bundethed til dåbsritualet, « København 1969 - Optrykt i Syn og sang s. 7-172.

11 »Digtet »De levendes land« belyst ud fra Grundtvigs prædikener og den bibelske poesi: I Syn og sang s. 173-209.

12 Thodberg: »Grundtvig som salmedigter.« I Grundtvig og grundtvigianismen i nyt lys s. 172. Ang. det gudstjenestlige nærvær se Niels Thomsens artikel »Grundtvig i oldkirkens spejl«. I Grundtvig og grundtvigianismen i nyt lys s. 197-209 og J.H. Schjørring: Grundtvigs billedsprog - og den kirkelige anskuelse s. 28ff udg. af Grundtvig-Selskabet bd. XXI 1990.

13 Thodberg »Vejen tilbage« DTT årg. 1989, nr. 52, s. 305.

14 Samme s. 304. 